\title{
Review of the potter wasps (Hymenoptera: Vespidae, Eumeninae) with a petiolate metasoma from Indonesian Archipelago
}

\author{
Hari Nugroho ${ }^{1, *}$, Pungki Lupiyaningdyah ${ }^{1}$, and Jun-ichi Kojima ${ }^{2}$ \\ ${ }^{1}$ Museum Zoologicum Bogoriense, Research Center for Biology, Indonesian Istitute of Sciences (LIPI), Widyasatwaloka \\ Building, Jalan Raya Cibinong KM 46, Cibinong, 16911, West Java, Indonesia \\ ${ }^{2}$ Natural History Laboratory, Faculty of Science, Ibaraki University, Mito, 310-8512 Japan
}

\begin{abstract}
The taxonomy and biogeography of potter wasps with a petiolate metasoma occurring in the Indonesian Archipelago are reviewed. Literature review and specimens examination were carried out for the present study. Within the Eumeninae, the wasps with a petiolate metasoma distributed in the region have been more or less well studied compared with those with a non-petiolate metasoma, but their generic affinities and the concepts of some species yet remain unestablished. A total of 80 species belonging to 16 genera of the "petiolate metasoma" are known to occur from the region. Sumatra, Java, Bali and Borneo have mainly Oriental eumenine fauna, including several areaspecific species of the Oriental genera. New Guinean fauna is comprised of Papua-Australian species of the widely distributed genera, together with widely distributed species and species endemic to New Guinea. The Wallacean fauna is constituted mainly with the area-specific species in the rather widely distributed genera; in the western part of Wallacea, they are represented mainly by widely distributed genera, together with Oriental genera; in the eastern part of Wallacea, they are constituted mainly by area endemic species of widely distributed Oriental genera. Widely distributed species generally show a wide range of variation in the marking patterns, and occurs sympatrically in some areas, even the peripheral populations usually characterized by the island(s)-specific marking patterns. Sympatric occurrences of forms with quite different color patterns in widely distributed species need further study to establish their taxonomic status, namely whether they are variations within a given area or different species.
\end{abstract}

\section{Introduction}

The subfamily Eumeninae is cosmopolitan and the largest subfamily in the Vespidae, consisting of more than 3,500 described species in 210 genera [1, 2, table 1]. Most of eumenine wasps are solitary even though they gather around a suitable nesting site and a few genera are known to be communal nesters $[2,3]$; some genera, such as Orancistrocerus and Calligaster, are subsocial. Many eumenine wasps construct nests with soil/mud mixed with relatively small amount of wasps' oral secretion or saliva, but Calligaster species use plant materials, and Epsilon is known to make their nests with plant-origin resin. Others use pre-existing cavities as their nesting places, and some are burrowers in the soil or wood, in which cell partitions or closing plugs are usually made of soil/mud or only sometimes plant material such as in Zethus $[2,4,5]$.
Eumenine wasps are predaceous on terrestrial insects, hunting mainly lepidopterous caterpillars or sometimes coleopterous larvae as food for their larvae $([6,7]$; Iwata, 1971 in [3]), and thus they are more or less at higher positions in a food web of terrestrial arthropods. They also visit flowers for nectar as their own energy source and thus are considered as potential pollinators of many plants $[5,6,7]$.

The Indonesian Archipelago, consisting of about 17,500 islands spreading from Sumatera in the west to New Guinea in the east, is known for the mega biodiversity. In the archipelago, four (Eumeninae, Stenogastrinae, Polistinae and Vespinae) of the six vespid subfamilies occur, of which the Eumeninae are the most diverse, with a total of 226 species in 51 genera so far recorded in the archipelago. The species recorded from Sarawak, Sabah, Brunei, Timor Leste and Papua New Guinea were included in the total biodiversity of

\footnotetext{
*Corresponding author: hntawon@gmail.com
} 
Eumeninae from Indonesian Archipelago, since the countries' border may have no biological meaning in the distribution of species.

Compared with the other three vespid subfamilies, to which the species belonging are all social, the taxonomy of the Eumeninae, in general, is yet much more poorly studied. Of the eumenine wasps known from the archipelago, 16 genera are among those treated as "potter wasps with a petiolate metasoma", which are characterized by having the first metasomal tergum at least twice as long as its apical width. These eumenine wasps with a petiolate metasoma were originally described in the genus Eumenes Latreille, 1802, genera in the so-called "Zethinae" and in the genus Labus.

Within the Eumeninae, the wasps with a petiolate metasoma distributed in the Indo-Australian Region have been more or less well studied compared with those with a non-petiolate metasoma, but their generic affinities and the concepts of some species yet remain unestablished. In the present study, the taxonomy and distribution (or biogeography) of potter wasps with a petiolate metasoma occurring in the Indonesian Archipelago are reviewed.

\section{Material and Methods}

\subsection{Specimens examined}

Examination of the specimens was carried out to study the morphological characters and clarify the distributional record, including determining the color/marking pattern within local populations. The specimens examined in the present study were those having deposited in the collections of the Museum Zoologicum Bogoriense, Cibinong, Bogor, Indonesia (MZB), the Natural History Collection at Ibaraki University, Mito, Japan (IUNH), the Systematic Entomology Institute, Hokkaido University Museum, Sapporo, Japan (SEIHU), the Natural Resources Inventory Center, National Institute for AgroEnvironmental Sciences, Tsukuba, Japan (NRIC), the National Museum of Nature and Science, Tsukuba, Japan (NSMT), and Institute of Ecology and Biological Resources, Hanoi, Vietnam (IEBR). In addition to those specimens in the collections, we have collected many specimens in various places in the Indonesian Archipelago, which were pinned and dried and deposited in the MZB and IUNH.

\subsection{Literature review}

A literature review was conducted to study the taxonomic history of Eumeninae at the genus, species and subspecies levels. Placements of the genera into the tribes are based on Hermes et al. [2], and the use of the "Labus group" is based on the authors' opinion, since the taxonomic treatment has not been carried out to clarify their phylogenetic position.

\section{Results and Discussion}

\subsection{Taxonomic history}

Hermes et al. [2] performed a comprehensive cladistic analysis of the Eumeninae and corroborated a natural classification of Eumeninae at the tribal level to recover the Eumenini, Odynerini and Zethini, which had been previously available. They also clearly showed that the potter wasps with a petiolate metasoma do not form a monophyletic group, but they are placed in all the three monophyletic tribes, namely Zethini, Odynerini and Eumenini, suggesting that the shape of the first metasomal segment is a weak character due to its high heterogeneity (see also [8]). However, their study did not include several Oriental and/or Afrotropical genera with a petiolate metasoma, such as Calligaster de Saussure, 1852, Labus de Saussure, 1867 and Cyrtolabulus van der Vecht, 1969, and their phylogenetic positions have not yet been discussed.

Many species originally described in the genus Eumenes have been transferred to several genera as the results of taxonomic works, including the establishment of new genera, by subsequent authors. The most important taxonomic studies on the Oriental Eumeninae with a petiolate metasoma are van der Vecht $[9,10,11,12,13]$ and Giordani Soika [14,15], which resulted in a proliferation of generic names in the Eumeninae: Omicroides Giordani Soika, 1935, Pseumenes Giordani Soika, 1935, Nortozumia van der Vecht, 1937, Coeleumenes van der Vecht, 1963 and Cyrtolabulus van der Vecht, 1969. These taxonomic treatments to split the preexisting genera were then continued by Giordani Soika [16] and Gusenleitner and Gusenleitner [17], in which Phimenes Giordani Soika, 1992 and Flavoleptus Giordani Soika, 1992, and Norteumenes Gusenleitner and Gusenleitner, 2013 were proposed.

The first record of potter wasps under Zethus from the Indonesian Archipelago was Cameron [18], who described Z. quadridentatus and Z. varipunctatus from Borneo. The other Oriental genus in the so-called "Zethini", Calligaster de Saussure, 1852, was described based on C. cyanoptera de Saussure, 1852 from Java, but since de Saussure (1855) treated Calligaster as a division of Zethus its taxonomic position had been ambiguously interpreted until Bequaert [19] definitely reinstated its generic status.

The Labus group is an Oriental and Ethiopian eumenine fauna. Two genera are recognized, Labus from the Oriental region and Cyrtolabulus from Indo-Ethiopian region. The genus Labus was described by de Saussure (1867) based on L. spiniger de Saussure, 1867 from Java, and since then received many interpretations, as it differs in many characters from its related genera [8, 20]. However, Bequaert [20] discussed the generic characters and established good diagnosis based on Ethiopian species. Van der Vecht [9] newly described another three species from Java, having contributed to a better understanding of the Labus fauna in the Indonesian 
Archipelago. The genus Cyrtolabus was described by van der Vecht [13] to accommodate two species from the Indian subcontinent; subsequently Cyrtolabulus van der Vecht, 1969 was established as a replacement name for Cyrtolabus van der Vecht, 1963.

\subsection{Diversity and biogeography}

Potter wasps with a petiolate metasoma in the Indonesian Archipelago consisting of 131 species-group taxa (80 species and 51 subspecies; table 1). The diversity of a petiolate metasomal genera in the archipelago consisted of widely distributed species (33) and endemic species (47). Sumatra, Java, Bali and Borneo are more likely representing Oriental element with less endemic species occurs; Sulawesi, Lesser Sunda Islands and Moluccas species more or less consisting mainly with the occurrence of endemic species; New Guinea species probably underrate, as they may less explore areas (Fig. 1).

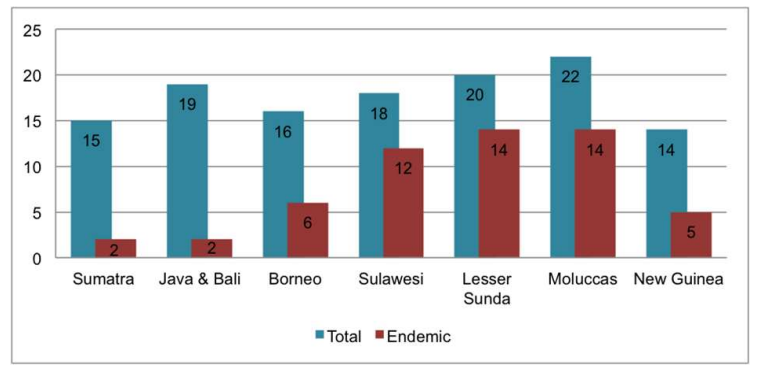

Fig. 1. Total species and number of endemic species of potter wasps with a petiolate metasoma in Indonesian Archipelago.

The tribe Eumenini includes four genera known to occur in the Indonesian Archipelago: Eumenes Latreille, 1802, Delta de Saussure, 1855, Phimenes Giordani Soika, 1992 and Omicroides Giordani Soika, 1935. Delta, Eumenes and Phimenes have widely distributed genera, while Omicroides is representing Oriental element. In this tribe, a total of 38 species in four genera with a petiolate metasoma are recognized from the Indonesian Archipelago. They are nine species in the genus Delta; 20 species in the genus Eumenes; the species in the monotypic genus Omicroides; and eight species in the genus Phimenes.

The tribe Odynerini is consist of eight genera known to occur in the Indonesian Archipelago: Coeleumenes van der Vecht, 1963, Ectopioglossa Perkins, 1912, Flavoleptus Giordani Soika, 1992, Norteumenes Gusenleitner \& Gusenleitner, 2013, Nortozumia van der Vecht, 1937, Pareumenes de Saussure, 1855, Pseudozumia de Saussure, 1875 and Pseumenes Giordani Soika, 1935. Flavoleptus, Norteumenes, Nortozumia and Pseudozumia are representing the Oriental genera in the Odynerini; Coeleumenes, Ectopioglossa, Pareumenes and Pseumenes are widely distributed genera and occur along the archipelago. In the Odynerini, the following 26 species in eight genera are recognized in the Indonesian archipelago: three species in the genus Pareumenes, three species in the genus Pseumenes, six species in the genus
Coeleumenes, seven species in the genus Ectopioglossa, two species in the genus Nortozumia, three species in the genus Pseudozumia, and each of the monotypic genera Flavoleptus and Norteumenes.

The tribe Zethini consists of three genera known to occur in the Indonesian Archipelago: Calligaster de Saussure, 1852, Elimus de Saussure, 1852 and Zethus Fabricius, 1804. In the Zethini, eight species in three genera are recognized in the Indonesian Archipelago; namely, three species in the genus Calligaster, four species in the genus Zethus and one species in the genus Elimus.

The Labus group is consisting only single genus known to occur in the Indonesian Archipelago, representing by eight species and distributed from Sumatra in the west to the Lesser Sunda Islands in the east. In the genus Labus, which may form, together with the Indo-Ethiopian genus Cyrtolabulus, an independent tribe, eight species are recognized in the Indonesian Archipelago.

With extremely high biodiversity characterized by a high level of endemism and complex geological history, the Indonesian Archipelago, the islands between continental Southeast Asia and Australia, has long attracted the attention of biologists from biogeographical and evolutionary (in terms of speciation) points of view. From the geological perspective, the Indonesian Archipelago is comprised of two major components, namely the Sunda Shelf component (Borneo, Sumatra, Java and Bali), where the fauna consists of mainly Oriental elements; and the Sahul Shelf component (New Guinea and its adjacent islands, including Aru Islands), where the fauna is comprised of Papua-Australian elements.

In the fauna of potter wasps with a petiolate metasoma of the Indonesian Archipelago, genera such as Calligaster, Zethus, Flavoleptus, Norteumenes, Nortozumia, Pseudozumia, Omicroides and Labus are the Oriental elements (Figs 2, 3), while Elimus is the PapuaAustralian element (Fig. 2). Sumatra, Java, Bali and Borneo, as a part of Sunda Shelf/Oriental component, have mainly Oriental eumenine fauna, including several area-specific species of the Oriental genera (Fig. 4). New Guinean fauna is comprised of Papua-Australian species of the widely distributed genera, together with widely distributed species and species endemic to New Guinea (Fig. 4).

The islands lying between the two shelves form a particular area, known as Wallacea, which is considered as the harbour of endemic species, as well as those on potter wasps with a petiolate metasoma (Fig. 4). The fauna of potter wasps with a petiolate metasoma in the Wallacea is constituted mainly with the area-specific species in the rather widely distributed genera, such as Eumenes, Delta, Phimenes, Coeleumenes, Ectopioglossa, Pareumenes, and Pseumenes; in the western part of Wallacea, namely Sulawesi and Lesser Sunda Islands, they are represented mainly by widely distributed genera, 
together with Oriental genera Calligaster, Zethus and Labus (Fig. 2); in the eastern part of Wallacea, namely the Moluccas (excluding Aru Islands), they are constituted mainly by area endemic species of widely distributed
Oriental genera. Occurrences of four Papua-Australian species in the Moluccas show that the area is the transition zone between Oriental and Australasian faunae (Fig. 4).

Table 1. An updated list of the Potter Wasps (Hymenoptera: Vespidae, Eumeninae) with a Petiolate Metasoma from Indonesia Archipelago (based and modified from Nugroho et al. [21]).

\begin{tabular}{c|c|c} 
No. & Species & Distribution \\
\hline EUMENINI \\
\hline Delta de Saussure, 1855
\end{tabular}

\section{Delta de Saussure, 1855}

1. a. Delta campaniforme campaniforme (Fabricius, India; Nepal; Myanmar; Vietnam; Thailand; Malaysia: 1775)

Peninsular Malaysia; Singapore; Philippines; Papua New Guinea; Australia; adventive in U. S. A.: Hawaii; Indonesia: Sumatra, Java, Bawean I., Kangean Is., Borneo, Sulawesi, Lombok, Bali, Sumba, Sumbawa, Timor, Moluccas (including Kei Is.), Papua.

b. Delta campaniforme keyense Giordani Soika, Indonesia: Moluccas (Kei Islands) 1972

c. Delta campaniforme megalospilus (Cameron, Indonesia: Papua 1911)

d. Delta campaniforme tricoloratum (Cameron, Indonesia: Papua 1906)

e. Delta campaniforme urvillei (de Saussure, Indonesia: Papua, Moluccas 1852)

2. $\quad$ Delta eremnum (van der Vecht, 1959)

3. a. Delta latreillei latreillei (de Saussure, 1852)

b. Delta latreillei petiolare (Schulz, 1905)

4. Delta nigriculum Giordani Soika, 1986

5. a. Delta pyriforme butonense (Schulz, 1905)

b. Delta pyriforme circinale (Fabricius, 1804)

Indonesia: Sumba, Flores

Indonesia: Papua, Java; Australia

Papua New Guinea; Admiralty Is.; Trobriand Is.; Solomon Islands; adventive in U. S. A.: Hawaii; Indonesia: Papua

Indonesia: Lombok, Sumbawa, Flores, Rinca I., Sumba

Thailand; Indonesia: Sulawesi (including Buton Island), Moluccas

Pakistan; India; Sri Lanka; Bhutan; Nepal; China; Myanmar; Thailand; Peninsular Malaysia; Philippines; Indonesia: Sumatra, Java, Krakatau, Bawean Island, Kangean Islands, Bali, Borneo, Sulawesi (including Buton Island), Lombok, Sumbawa, Komodo, Flores, Timor, Tanimbar Islands, Sumba, Moluccas, New Guinea; adventive in U. S. A.: Hawaii.

c. Delta pyriforme malayanum (Giordani Soika, 1958)

d. Delta pyriforme miraculum Gusenleitner, 2008

e. Delta pyriforme nigrocinctum Giordani Soika, 1993

f. Delta pyriforme novaeguineae (Giordani Soika, 1935)

g. Delta pyriforme rufonigerrimum Giordan
Soika, 1973

6. Delta rumphii (van der Vecht, 1959)
Indonesia: Sumatra

Indonesia: Tanimbar Islands

Indonesia: Sumba

Papua New Guinea

Indonesia: Moluccas

Indonesia: Moluccas 
7. Delta sciarum (van der Vecht, 1959)

8. Delta viridipenne (van der Vecht, 1959)

9. Delta wieneckei (van der Vecht, 1959)

\section{Eumenes Latreille, 1802}

1. Eumenes achterbergi Giordani Soika, 1992

2. Eumenes affinissimus de Saussure, 1852

3. Eumenes agillimus Dalla Torre, 1894

4. Eumenes architectus Smith, 1859

5. Eumenes batantanensis Nugroho, 2010

6. a. Eumenes blandus blandus Smith, 1861

b. Eumenes blandus sumbanus Giordani Soika, 1992

7. Eumenes dichrous Maindron, 1882

8. Eumenes diligens Smith, 1864

9. Eumenes dorycus Maindron, 1882

10. Eumenes floralis Smith, 1859

11. Eumenes inconspicuus Smith, 1858

12. Eumenes insolens Smith, 1865

13. Eumenes koriensis Giordani Soika, 1992

14. Eumenes macrops de Saussure, 1852

15. Eumenes multipictus de Saussure, 1855

16. Eumenes piriformis de Saussure, 1862

17. a. Eumenes pius nigrorufus Giordani Soika, 1992

b. Eumenes pius pius Giordani Soika, 1986

18. Eumenes simplicilamellatus Giordani Soika, 1935

19. Eumenes tricolor Smith, 1861

20. Eumenes truncatus Nugroho, 2010

Omicroides Giordani Soika, 1935

1. Omicroides singularis (Smith, 1858)
Indonesia: Lombok, Sumba, Sumbawa, Komodo Island, Flores

Indonesia: Sumatra (Riau Islands)

Indonesia: Timor

Indonesia: Sulawesi

Kyrgyzstan; India; Myanmar; Malaysia: Peninsular Malaysia; Indonesia: Java

Indonesia: Papua, Moluccas

India; China; Myanmar; Malaysia: Peninsular Malaysia; Singapore; Philippines; Indonesia: Sumatra, Java (including Krakatau, Kangean Is.), Sulawesi, Moluccas

Indonesia: Papua (Batanta Island)

Indonesia: Moluccas

Indonesia: Sumba

Indonesia: Moluccas

Indonesia: Moluccas (Buru Island)

Papua New Guinea; Indonesia: Papua

Indonesia: Sulawesi

Vietnam, Thailand; Malaysia: Peninsular Malaysia, Sarawak; Indonesia [Sumatra, Kalimantan, Krakatau Islands, Java, Bali, Lesser Sunda Islands (Sumbawa), Sulawesi, Ceram, Papua]

Indonesia: Moluccas

Indonesia: Sumba

India; Malaysia: Peninsular Malaysia; Indonesia: Bali

Vietnam; Malaysia: Peninsular Malaysia, Sarawak; Singapore; China; Indonesia: Sumatra (including Bangka Island), Java, Kalimantan

Nepal; Philippines; Thailand; Indonesia: Sumatra, Java, Sulawesi, Lesser Sunda Islands (Lombok, Sumbawa)

Indonesia: Sumba

Indonesia: Komodo, Timor

Papua New Guinea; Australia; Indonesia: Papua

Indonesia: Sulawesi, Moluccas

Indonesia: Papua

Vietnam; Malaysia: Sarawak; Myanmar; Thailand; Singapore; Indonesia: Sumatra, Kalimantan

\section{Phimenes Giordani Soika, 1992}

1. a. Phimenes arcuatus amboinensis (van der Vecht, Indonesia: Moluccas 1959)

b. Phimenes arcuatus arcuatus (Fabricius, 1775)
Papua New Guinea; Australia; Indonesia: Moluccas (Damma, Aru and Kei Islands), Papua (including Raja Ampat Islands, Biak Island) 
c. Phimenes arcuatus buruanus (van der Vecht, Indonesia: Moluccas (Buru Island) 1959)

d. Phimenes arcuatus lyratus (van der Vecht, Indonesia: Moluccas 1959)

e. Phimenes arcuatus muruensis (van der Vecht, Papua New Guinea 1960)

f. Phimenes arcuatus obiensis (van der Vecht, Indonesia: Moluccas (Obi Island) 1959)

g. Phimenes arucatus praslinius (Guérin- Papua New Guinea: Bismarck Islands. Méneville, 1831)

h. Phimenes arcuatus transilis (van der Vecht, Indonesia: Papua (Misool Island) 1959)

2. a. Phimenes curvatus sangirensis (van der Vecht, Indonesia: Sulawesi (Sangir Islands) 1959)

b. Phimenes curvatus talaudense (van der Vecht, Indonesia: Sulawesi (Talaud Islands) 1959)

3. a. Phimenes flavopictus baweanus (van der Vecht, Indonesia: Bawean Island (north coast of Java) 1959)

b. Phimenes flavopictus blanchardi (de Saussure, 1852)

c. Phimenes flavopictus continentalis (Zimmermann, 1931)

d. Phimenes flavopictus dammae (Dalla Torre 1904)

e. Phimenes flavopictus engganensis (van der Vecht, 1959)

f. Phimenes flavopictus kalimantenus (van der Vecht, 1959)

g. Phimenes flavopictus maidli (Giordani Soika, 1934)

h. Phimenes flavopictus simalurensis (Giordani Soika, 1934)

i. Phimenes flavopictus telonus (van der Vecht, 1959)

j. Phimenes flavopictus timorensis (van der Vecht, 1959)

k. Phimenes flavopictus umbripennis (van der Vecht, 1959)

4. a. Phimenes fulvipennis fulvipennis (Smith, 1857)

b. Phimenes fulvipennis niasanus (Zimmermann, 1931)

c. Phimenes fulvipennis saleyerensis (Zimmermann, 1931)

5. a. Phimenes incola aruense (Giordani Soika, 1935)

b. Phimenes incola incola (Giordani Soika, 1935)

Papua); Australia (Queensland)

Indonesia: Java (including Panaitan I., Karimunjawa and Kangean Is.), Bali, Lombok, Sumbawa, Sumba, Komodo, Flores.

India: Arunachal Pradesh, Karnataka, Kerala, Meghalaya, Sikkim, Uttarakhand, West Bengal; Nepal; China; Myanmar; Thailand; Vietnam; Malaysia; Indonesia: Sumatra, Krakatau.

Indonesia: Moluccas [Damma I. (= Pulau Damar), Kei]

Indonesia: Sumatra (Enggano Island)

Malaysia: Sarawak; Indonesia: Kalimantan

Malaysia: Peninsular Malaysia; Indonesia: Mentawai Islands (west coast of Sumatra)

Indonesia: Simalur Island [=Simeleue Island, Aceh, northwest of Sumatra]

Indonesia: Batu Islands (west coast of Sumatra)

Indonesia: Timor, Wetar Island, Tanimbar Islands (Yamdena Island)

Indonesia: Nias Island (west coast of Sumatra)

Indonesia: Sulawesi (including Buton Island), Moluccas (Sula Islands)

Indonesia: Nias Island (west coast of Sumatra)

Indonesia: Selayar Islands (South of Sulawesi)

Indonesia: Moluccas (Aru and Kei Islands, near Papua New Guinea

c. Phimenes incola mauritsi (van der Vecht, 1959) Indonesia: Papua 
d. Phimenes incola octomaculatus (van der Vecht, Indonesia: Misool Island (Northwest of Papua) 1959)

e. Phimenes incola zonites (van der Vecht, 1959) Papua New Guinea; Indonesia: Papua

6. $\quad$ Phimenes perplexus (Smith, 1864)

Indonesia: Moluccas (Buru Island)

7. $\quad$ Phimenes violaceipennis (van der Vecht, 1959)

Indonesia: Java, Bali

8. $\quad$ Phimenes zamenes (van der Vecht, 1959)

Indonesia: Sulawesi, Moluccas (Sula Islands)

\section{ODYNERINI}

Coeleumenes van der Vecht, 1963

1. a. Coeleumenes impavidus conformis van der Indonesia: Java Vecht, 1963

b. Coeleumenes impavidus impavidus (Bingham, India; Sri Lanka; Myanmar; Thailand; Malaysia; 1897)

Singapore; Indonesia: Kalimantan.

2. Coeleumenes multicolor (Giordani Soika, 1935) Indonesia: Sumba, Sumbawa

3. Coeleumenes ruficrus van der Vecht, $1963 \quad$ Indonesia: Moluccas

4. Coeleumenes secundus (Dalla Torre, 1889) Indonesia: Moluccas

5. Coeleumenes timorensis van der Vecht, 1963 Indonesia: Timor

6. Coeleumenes vindex (Smith, 1859) Indonesia: Sulawesi

\begin{tabular}{|c|c|c|c|}
\hline & & Ectopioglossa Perkins, 1912 & \\
\hline 1. & & Ectopioglossa henseni Gusenleitner, 1990 & Thailand; Borneo: Baret-Sekadu, West Kalimantan \\
\hline 2. & & Ectopioglossa mediana (Smith, 1864) & Indonesia: Moluccas (Ceram Island) \\
\hline 3. & & Ectopioglossa mutata Gusenleitner, 1991 & Indonesia: Sulawesi \\
\hline 4. & & Ectopioglossa palustris van der Vecht, 1963 & Indonesia: Java \\
\hline \multirow[t]{2}{*}{5.} & a. & Ectopioglossa polita polita (Smith, 1861) & Indonesia: Moluccas (Bacan Island) \\
\hline & b. & Ectopioglossa polita volatilis (Smith, 1864) & $\begin{array}{l}\text { Papua New Guinea; Indonesia: Papua (including } \\
\text { Misool Island), Moluccas (Aru Islands) }\end{array}$ \\
\hline 6. & & Ectopioglossa sublaevis (Smith, 1857) & $\begin{array}{l}\text { Vietnam; Malaysia: Sarawak; Philippines; Indonesia: } \\
\text { Sumatra, Java, Kalimantan }\end{array}$ \\
\hline \multirow[t]{2}{*}{7.} & & Ectopioglossa sumbana van der Vecht, 1963 & Indonesia: Sumba \\
\hline & & Flavoleptus Giordani Soika,1992 & \\
\hline 1. & & Flavoleptus flavobalteatus (Cameron, 1903) & Malaysia: Sarawak, Sabah \\
\hline 1. & & $\begin{array}{l}\text { Norteumenes Gusenleitner \& Gusenleiter, } \\
\mathbf{2 0 1 3} \\
\text { Norteumenes hiesli Gusenleitner \& } \\
\text { Gusenleitner, } 2013\end{array}$ & Sabah \\
\hline \multirow{2}{*}{\multicolumn{2}{|c|}{2.}} & $\begin{array}{l}\text { Nortozumia van der Vecht, } 1937 \\
\text { Nortozumia pulchella (Smith, 1858) } \\
\text { Nortozumia rufofemorata rufofemorata } \\
\text { (Cameron, 1903) }\end{array}$ & $\begin{array}{l}\text { Malaysia: Sarawak } \\
\text { Malaysia: Sarawak }\end{array}$ \\
\hline & & Pareumenes de Saussure, 1855 & \\
\hline \multirow{4}{*}{$\begin{array}{l}1 . \\
2 . \\
3 .\end{array}$} & & Pareumenes nigerrimus van der Vecht, 1963 & Indonesia: Sumbawa, Sumba, Flores, Timor \\
\hline & & Pareumenes pullatus (Smith, 1864) & Indonesia: Moluccas (Ceram Island) \\
\hline & a. & $\begin{array}{l}\text { Pareumenes quadrispinosus interjectus van der } \\
\text { Vecht, } 1937\end{array}$ & $\begin{array}{l}\text { Malaysia: Peninsular Malaysia, Sarawak; Indonesia: } \\
\text { Sumatra }\end{array}$ \\
\hline & b. & $\begin{array}{l}\text { Pareumenes quadrispinosus javanus van der } \\
\text { Vecht, } 1937\end{array}$ & Indonesia: Java \\
\hline
\end{tabular}

Pseudozumia de Saussure, 1875 
1. a. Pseudozumia indica borneana Giordani Soika, 1960

b. Pseudozumia indica indica (de Saussure, 1855)

c. Pseudozumia indica wallacei (Meade-Waldo, 1910)

2. Pseudozumia orientalis (Gribodo, 1892)

3. Pseudozumia viridipennis Giordani Soika, 1960
Malaysia (including Sarawak); Indonesia: Kalimantan

India; Sri Lanka; China; Taiwan; Vietnam; Malaysia: Peninsular Malaysia; Borneo: Sarawak; Indonesia: Sumatra, Java, Bali, Lombok.

Indonesia: Sumatra

Indonesia: Kalimantan

Indonesia: Sulawesi

\section{Pseumenes Giordani Soika, 1935}

1. a. Pseumenes depressus hamanni van der Vecht, Indonesia: Sulawesi 1963

b. Pseumenes depressus insignis van der Vecht, Indonesia: Sumba 1963

c. Pseumenes depressus pictifrons (Smith, 1861) Indonesia: Sulawesi

d. Pseumenes depressus thoracicus (van der Indonesia: Java, Bali Vecht, 1937)

2. a. Pseumenes eximius arcuatoides van der Vecht, Indonesia: Moluccas (Ambon), Papua. 1963

b. Pseumenes eximius eximius (Smith, 1861)

Indonesia: Moluccas

3. Pseumenes laboriosus (Smith, 1861)

Indonesia: Sulawesi

\section{ZETHINI}

\section{Calligaster de Saussure, 1852}

1. Calligaster cyanoptera de Saussure, 1852

Indonesia: Java, Sumatra

2. $\quad$ Calligaster etchellsii (Cameron, 1909)

Malaysia: Sarawak

3. Calligaster viridipennis Giordani Soika, 1960

Indonesia: Sulawesi

\section{Elimus de Saussure, 1852}

1. Elimus papuanus Borsato and Giordani Soika, Papua New Guinea 1995

\section{Zethus Fabricius, 1804}

1. Zethus celebensis Giordani Soika, 1960

Indonesia: Sulawesi

2. Zethus mandibularis Giordani Soika, 1995

Indonesia: Flores, Sumba

3. Zethus quadridentatus Cameron, 1902

Borneo

4. Zethus varipunctatus Cameron, 1902

Malaysia: Peninsular Malaysia, Serawak

\section{Labus Group}

\section{Labus de Saussure, 1867}

1.

Labus amoenus van der Vecht, 1935

2. Labus angularis van der Vecht, 1935

3. Labus clypeatus van der Vecht, 1935

4. Labus robustus Li \& Carpenter, 2018

5. Labus rufomaculatus van der Vecht, 1963

6. Labus spiniger de Saussure, 1867

7. Labus sumatrensis Giordani Soika, 1991

8. Labus vandervechti Giordani Soika, 1960
India: Assam; China; Laos; Vietnam; Malaysia; Singapore; Indonesia: Java, Sumatra (including Bangka Island)

India; China; Myanmar; Thailand; Indonesia: Java Indonesia: Java; Vietnam

Indonesia: Java

Indonesia: Sumba

Indonesia: Sumatra, Java; China

Indonesia: Sumatra

Indonesia: Lombok, Sumbawa, Flores 


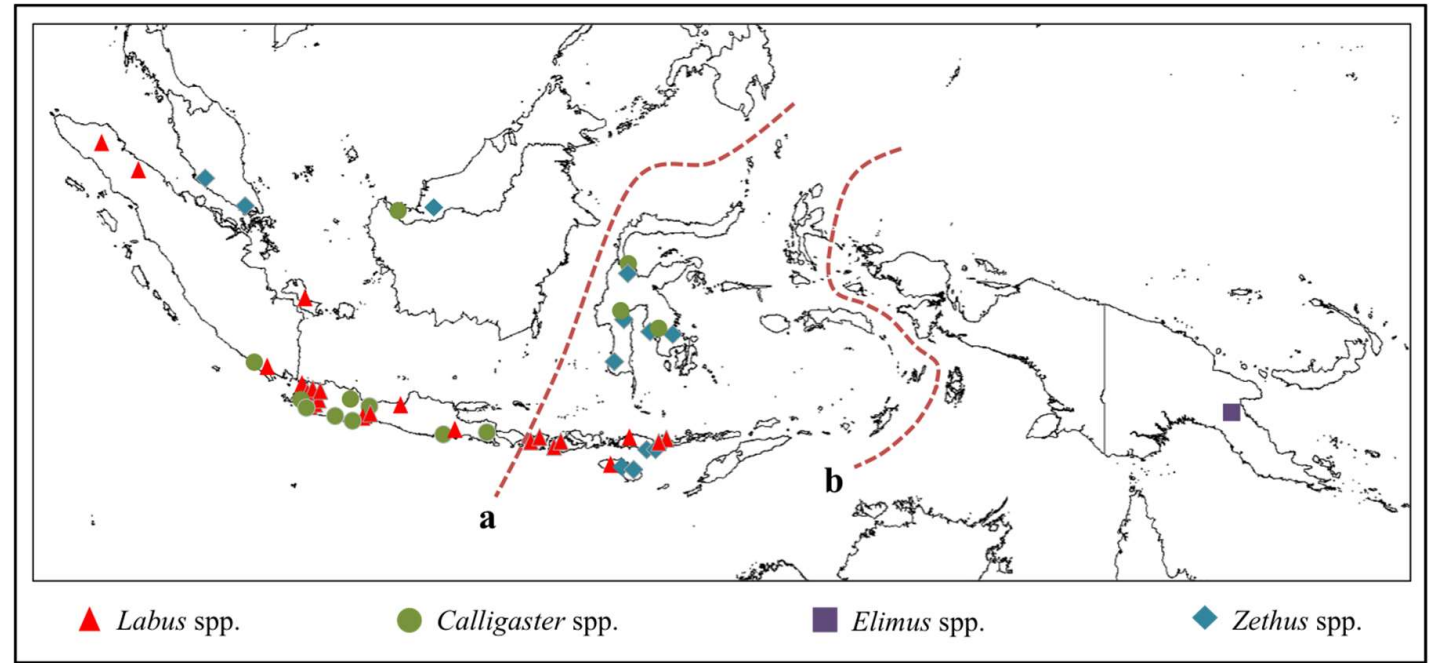

Fig. 2. Map showing the collection records of the Labus group and Zethini at the generic level in the Indonesian Archipelago. (a) Wallace's line. (b) Lydekker's line

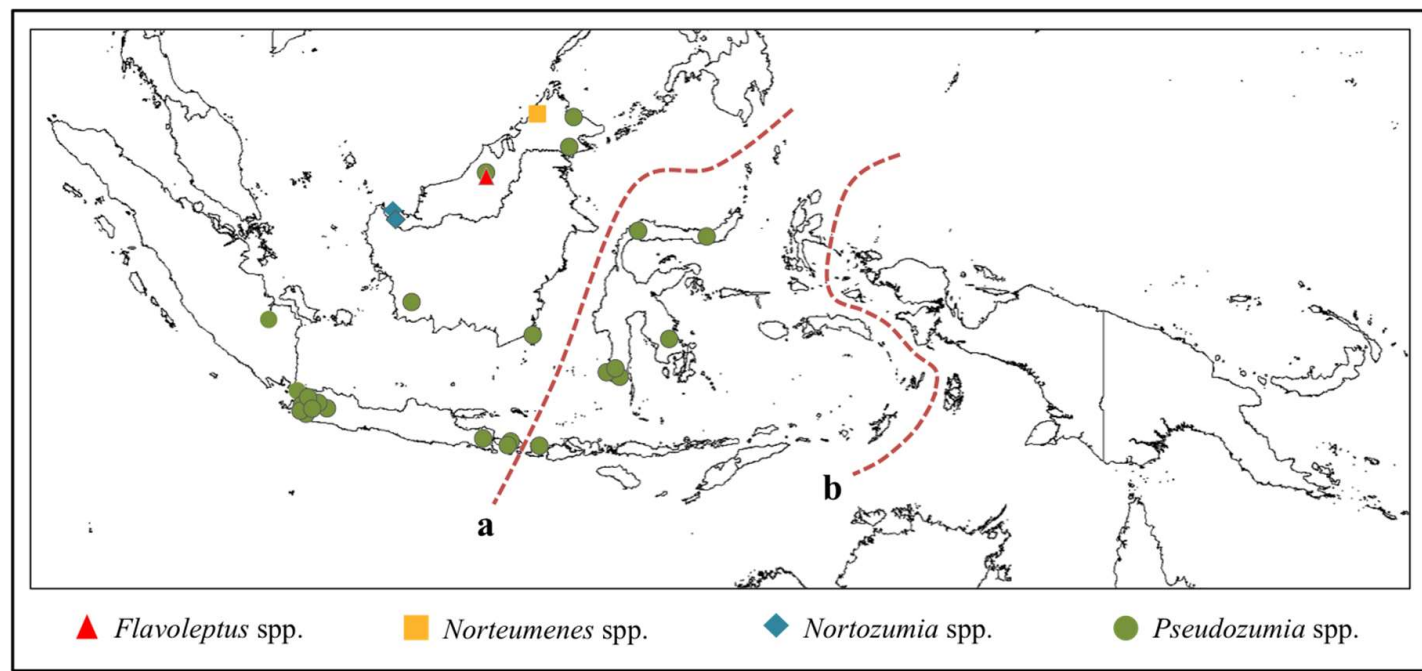

Fig. 3. Map showing the collection records of Oriental genera of Odynerini in the Indonesian Archipelago. (a) Wallace's line. (b) Lydekker's line

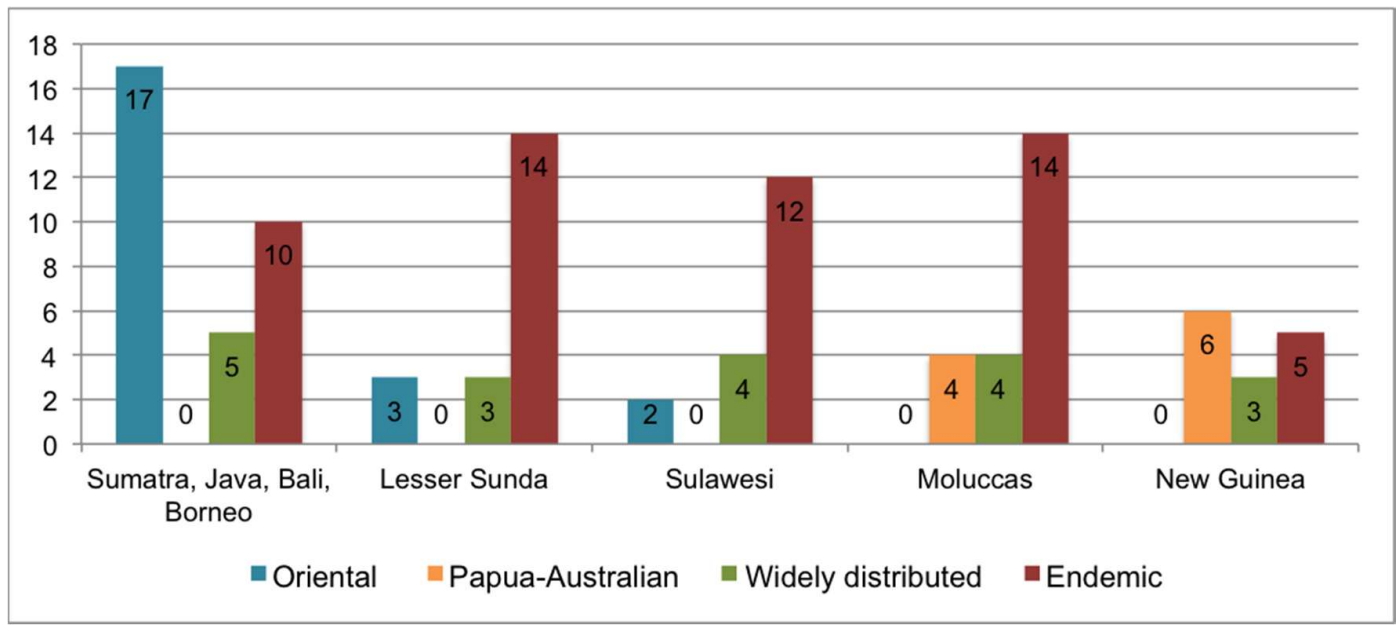

Fig. 4. Number of species of the potter wasps with a petiolate metasoma in the Indonesian Archipelago. Sumatra, Java, Bali and Borneo are part of Sunda Shelf; Wallacea consists of Lesser Sunda, Sulawesi and Moluccas; New Guinea is Sahul Shelf component, and including Aru Islands 


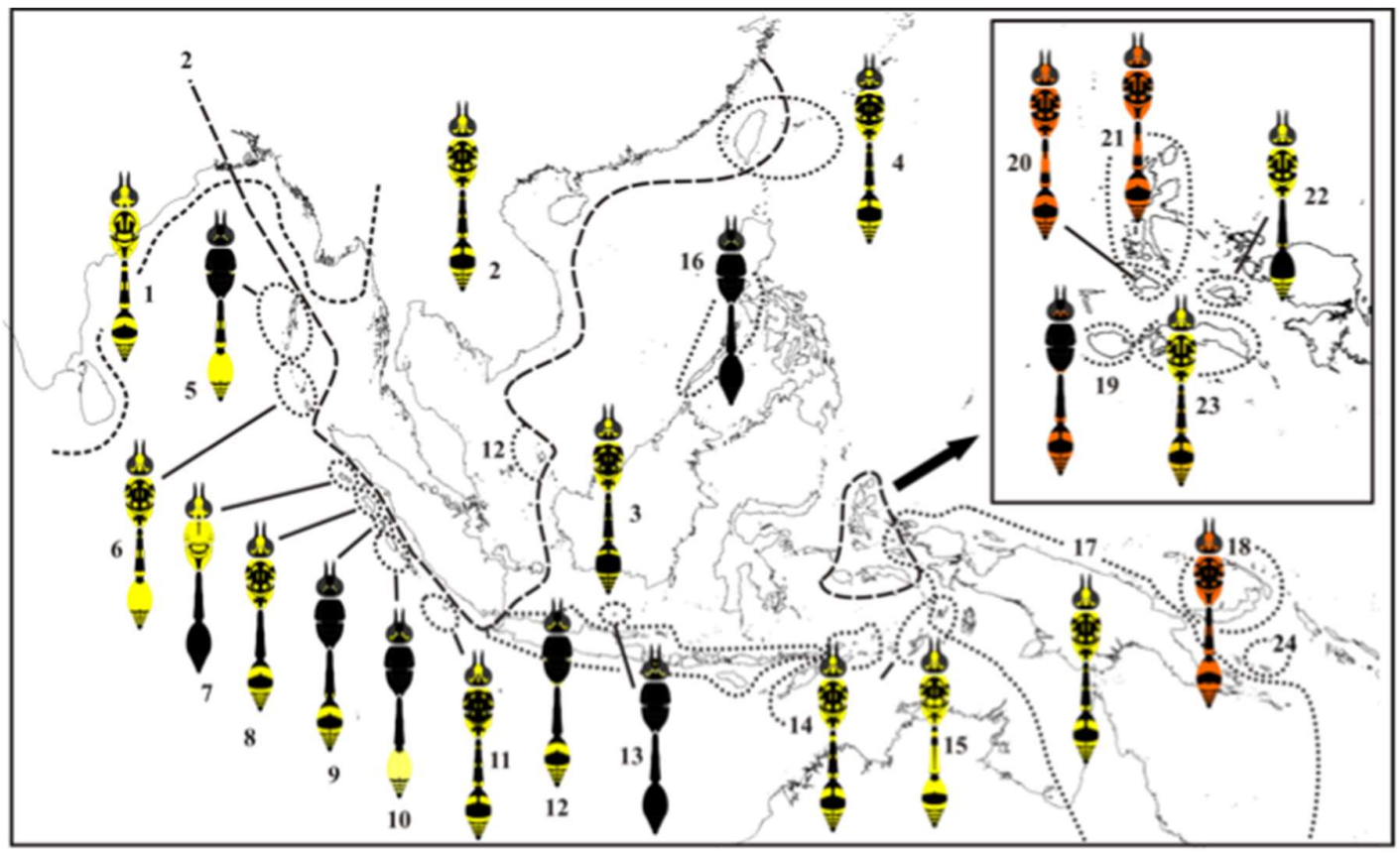

Fig. 5. Marking pattern and distribution of the subspecies Phimenes flavopictus and Phimenes arcuatus [modified from van der Vecht (1959)]: 1-16: Phimenes flavopictus. (1) P. f. flavopictus. (2) P.f. continentalis. (3) P. f. kalimantenus. (4) P. f. formosanus. (5) P. f. andamanicus. (6) P. f. nicobaricus. (7) P. f. simalurensis. (8) P. f. umbripennis. (9) P. f. telonus. (10) P. f. maidli. (11) $P$. f. engganensis. (12) P. f. blanchardi. (13) P. f. baweanus. (14) P. f. timorensis. (15) P. f. dammae. (16) P. f. aidrytus. 17-24: Phimenes arcuatus. (17) P. a. arcuatus. (18) P. a. praslinius. (19) P. a. buruanus. (20) P. a. obiensis. (21) P. a. lyratus. (22) P. a. transilis. (23) P. a. amboinensis. (24) P. a. muruensis

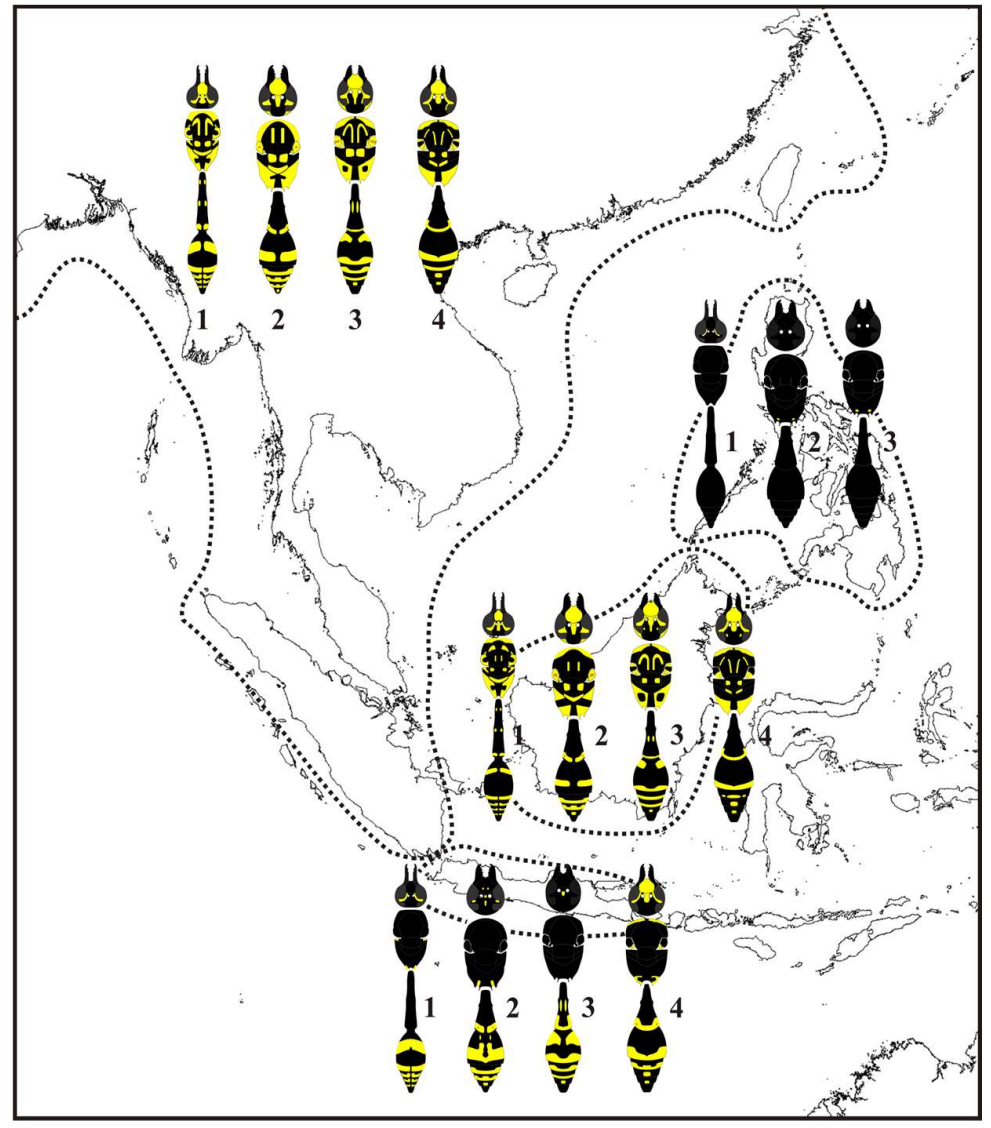

Fig. 6. Map showing the parallel distribution of marking pattern in four species: (1) Phimenes flavopictus, (2) Pareumenes quadrispinosus, (3) Pseumenes depressus, (4) Coeleumenes impavidus 


\subsection{Color variation and marking pattern}

Species that are widely distributed generally show wide range of variation in the marking patterns, such as Phimenes flavopictus, $P$. arcuatus, Pareumenes quadrispinosus, Pseumenes depressus and Coeleumenes impavidus. The marking patterns of two closely related polymorphic species, Oriental Phimenes flavopictus and Papuan $P$. arcuatus, are remarkable (Fig. 5). Their marking patterns consist of those of the "mainland populations (or subspecies)" that inhabit a wide range of geographical areas and those of "peripheral populations (or subspecies)" inhabiting adjacent islands (van der Vecht, 1961). The mainland subspecies of P. flavopictus, flavopictus in continental Asia (Fig. 5 [1]), continentalis occurring in continental Asia and Sumatra (Fig. 5 [2]) and formosanus in Taiwan (Fig. 5 [4]), are more or less extensively marked with yellow, and occur sympatrically in some areas. The Bornean subspecies, kalimantenus (Fig. 5 [3]), has the marking pattern similar to those of these mainland subspecies but its yellow markings are constantly narrower or reduced. The peripheral subspecies of $P$. flavopictus inhabiting small islands from the Andaman Islands, through the group of islands off the west coast of Sumatra and Java, to Lesser Sunda Islands and Tanimbar, and also the Philippines, are characterized by the island(s)-specific marking patterns. In some subspecies, mosaic marking patterns are recognized, that is, in some body parts yellow markings are more extensive than those in mainland subspecies and in other body parts the yellow markings are reduced or even absent (Fig. 5 $[5-7,9,10])$. In other subspecies, yellow markings are much reduced, or even the body is nearly entirely black (Fig. $5[12,13,16])$, while others have the marking pattern with yellow marking only slightly reduced and/or only slightly extensive than those of the mainland subspecies (Fig. $5[8,11,14,15]$ ).

The mainland subspecies of $P$. arcuatus, arcuatus (Fig. 5 [17]), has the marking pattern similar to those of the mainland subspecies of $P$. flavopictus, and occurs in New Guinea (including Aru Islands) and North Queensland of Australia, and also in Kei Islands, where P. flavopictus dammae [Fig. 5 (15)] with the marking pattern similar to $P$. a. arcuatus occurs. The peripheral subspecies of $P$. arcuatus are found in the Moluccas and adjacent islands of New Guinea [Fig. 5 (18-24)]. They show, as the peripheral subspecies of $P$. flavopictus, the island(s)-specific marking patterns, which are generally characterized by orange markings instead of yellow markings [Fig. 5 (18-21)] or reduction of yellow markings [Fig. 5 (22)]. Subspecies ambonensis is similar to mainland subspecies, but the markings on the metasoma are slightly darker [Fig. 5 (23)].

As mentioned above, their marking patterns often consist of those of the "mainland populations (or subspecies)" that inhabit a wide range of geographical areas and those of "peripheral populations (or subspecies)" inhabiting adjacent islands; the mainland subspecies more or less show similar markings with only slightly reduced and/or only a slightly extensive variation and occurs sympatrically in some areas, while the peripheral subspecies usually characterized by the island(s)-specific marking patterns (Fig. 5). Sympatric occurrences of forms with quite different color patterns in widely distributed species may invite us to make a further intensive study to establish their taxonomic status, namely whether they are variations within a given area or different species.

Body color markings in aculeate wasps are commonly found to be contrasted patterns of bright and dark (usually black) color as a warning signal to their predators, despite the fact that the degree of darkness drastically varies among local populations of a given species. The color variations in the polymorphic and widely distributed eumenine species with a petiolate metasoma in the Indonesian Archipelago show mosaic pattern of distribution but they do not change along geographical clines, and thus such the color variations have been more likely driven by aposematic pressure rather than by abiotic factors. Sympatric occurrences of nearly the same marking pattern in four species (Phimenes flovopictus, Pareumenes quadrispinosus, Pseumenes depressus, and Coeleumenes impavidus), probably have resulted from the Müllerian mimicry, and are recognized in the continental Asia, the Philippines, Borneo and Java (Fig. 6).

The present study was supported by the Japan Society for the Promotion of Science (JSPS). We are thankful to Dr. Masahiro Ohara (Systematic Entomology Institute, Hokkaido University Museum), Dr. Akihiko Shinohara (National Museum of Nature and Science, Tsukuba, Japan), Dr. Shinichi Yoshimatsu (Natural Resources Inventory Center, National Institute for AgroEnvironmental Sciences, Tsukuba, Japan) and Dr. Nguyen Thi Phuong Lien (Institute of Ecology and Biological Research, Hanoi, Vietnam) for arranging loans of the specimens.

\section{References}

1. K.M. Pickett \& J.M. Carpenter, Arthropod Syst Phylo 68: 3-33 (2010)

2. M.G. Hermes, G.A.R. Melo, J.M. Carpenter, $\begin{array}{lll}\text { Cladistic } & \text { (2013): } & 1-32\end{array}$ https://doi.org/10.1111/cla.12059

3. Sk. Yamane, Insecta Matsumurana. Series entomology. New series 43: 1-189 (1990)

4. R.M. Bohart \& L.A. Strange, University of California Publications in Entomology 40: 1-208 (1965)

5. J.H. Hunt, The Evolution of Social Wasps (Exford University Press, New York, 2007)

6. J. Kojima, New Entomologist 42: 4-7 (1993)

7. J.M. Carpenter \& J.W. Wenzel, Natural History Bulletin of Ibaraki University (3): 9-14 (1999)

8. H. de Saussure, Reise der Österreichischen Fregatte Novara um die Erde in den Jahren 1857, 1858, 1859 unter den Befehlen des Commodòre B. von Wüllerstorf-Urbair. (Zoologischer Theil. 2 Hymenoptera nebest einem Supplement von Dr. J. Sichel. Der Kaiserlich- 
Königlichen Hof und Staatsdruckerei in Commission bei Karl Gerold's Sohn, 1867)

9. J. van der Vecht, Treubia 15: 157-167 (1935)

10. J. van der Vecht, Treubia 16: 261-293 (1937)

11. J. van der Vecht, Zoologische Verhandelingen 41: 171 (1959)

12. J. van der Vecht, Evolution 15: 468-477 (1961)

13. J. van der Vecht, Zoologische Verhandelingen 60: 3$113(1963)$

14. A. Giordani Soika, Annali di Museo Civico di Storia Naturale di Genova 57: 1-38 (1935(1934))

15. A. Giordani Soika, Bollettino della Societa Veneziana Storia Naturale 2: 130-279 (1941)

16. A. Giordani Soika, Lavori Società veneziana di Scienze naturali 17: 41-68 (1992)

17. J. Gusenleitner \& F. Gusenleitner, Linzer Biologische Beitrage 45 (1): 133-139 (2013)

18. P. Cameron, Entomologist 35: 312-315 (1902)

19. J.C. Bequaert, Ann Mag Nat Hist (10) 2: 138-176 (1928) https://doi.org/10.1080/00222932808672864

20. J.C. Bequaert, B Am Mus Nat Hist 39: 1-384 (1918)

21. H. Nugroho, J. Kojima, J.M. Carpenter, Treubia 38: 71-186

http://dx.doi.org/10.14203/treubia.v38i0.547 